\title{
New Counts for Chara fibrosa Complex
}

\author{
L. Labh and B. N. Verma \\ Phycological Laboratory, University Department of Botany, University of Bihar, \\ Muzaffarpur-842 001, Bihar, India
}

Accepted February 18, 1985

The nuclear cytology of as many as seven taxa belonging to the Chara fibrosa Complex of Wood and Imahori (1965) has so far been worked out by the previous workers (Hotchkiss 1963, Noor 1965, Sarma and Khan 1965 a, b, c, 1966, 1967 a, b, c, Sinha and Verma 1970, Sinha and Noor 1971, Sarma and Ramjee 1971, Noor and Mukherjee 1975, Ramjee and Bhatnagar 1978). In the present investigation four taxa of this complex viz. Chara fibrosa var. fibrosa f. curtissii (T.F.A. Rob.) R.D. Wood, em., Chara fibrosa var. hydropitys f. hydropitys (Reich) R.D. Wood, em., Chara fibrosa var. hydropitys f. schneckii (T.F.A. ex Rob.) R.D. Wood, em., Chara fibrosa var. Wood, em. and f. fibrosa (T.F.A. ex Rob.) R.D. Wood, em. have been cytologically investigated and their chromosome numbers have been ascertained. There appears to be no previous reporting of chromosome number in first three taxa.

The present count in the last named taxon differs from the previous reports (Sarma and Khan 1965, Ramjee and Bhatnagar 1978).

Materials and methods

The four taxa under investigation were collected from three districts of North Bihar during different seasons of the year (Table 1).

Fixations of the materials for cytological preparation were made in aceticethanol $(1: 1)$ on the collection spot during morning hours (8-10 A.M.). Ironalum-acetocarmine technique as devised by Godward (1948) was adopted for cytological preparations.

\section{Observations}

The chromosome numbers were ascertained in the antheridial filaments which are supposed to be the ideal organ for the chromosome study being devoid of any pigments. All the four taxa revealed remarkable similarities in respect of interphase nuclei being constantly almost spherical structure bounded by a distinct nuclear membrane. The diameter of these nuclei of respective taxa was measured and presented in the Table 2. At metaphase the chromosomes were seen highly condensed rod shaped and well spreaded making the count easy. The details of interphase nuclei, the length of the chromosome and the haploid chromosome numbers ascertained for the four taxa under study may be seen in the Table 2 (Figs. $1-5)$.

The diameter of interphase nuclei among the four taxa were found ranging 
Table 1.

\begin{tabular}{|c|c|c|c|}
\hline $\begin{array}{l}\text { Sl. } \\
\text { no. }\end{array}$ & Name of the taxa & Habitat & $\begin{array}{l}\text { Time of } \\
\text { collection }\end{array}$ \\
\hline 1 & $\begin{array}{l}\text { Chara fibrosa var. fibrosa f. } \\
\text { fibrosa (T. F. A. ex. Rob.) } \\
\text { R. D. Wood, em. }\end{array}$ & $\begin{array}{l}\text { Paddy field, Narainpur, } \\
\text { Muzaffarpur }\end{array}$ & December 1978 \\
\hline 2 & $\begin{array}{l}\text { Chara fibrosa var. fibrosa f. } \\
\text { curtissii (T. F. A. ex Rob.) }\end{array}$ & $\begin{array}{l}\text { Paddy field, Thawe } \\
\text { and Hathwa, } \\
\text { Gopalganj }\end{array}$ & February 1977 \\
\hline 3 & $\begin{array}{l}\text { Chara fibrosa var. hydropitys } \\
\text { f. hydropitys (Reich) R. D. } \\
\text { Wood. em. }\end{array}$ & $\begin{array}{l}\text { A ditch, Hathwa, } \\
\text { Gopalganj }\end{array}$ & October 1976 \\
\hline 4 & $\begin{array}{l}\text { Chara fibrosa var. hydropitys } \\
\text { f. schneckii (T. F. A. ex. } \\
\text { Rob.) R. D. Wood, em. }\end{array}$ & $\begin{array}{l}\text { A ditch, along } \\
\text { railway line, } \\
\text { Chapra, Saran }\end{array}$ & December 1978 \\
\hline
\end{tabular}

Table 2. The diameter of interphase nuclei, chromosome numbers and their length as ascertained for the four taxa by the authors

\begin{tabular}{|c|c|c|c|c|}
\hline $\begin{array}{l}\text { Sl. } \\
\text { no. }\end{array}$ & Name of the taxa & $\begin{array}{l}\text { Diameter of } \\
\text { interphase } \\
\text { nuclei } \\
(\mu \mathrm{m})\end{array}$ & $\begin{array}{c}\text { Chromosome } \\
\text { number }\end{array}$ & $\begin{array}{l}\text { Length of the } \\
\text { chromosome } \\
\qquad(\mu \mathrm{m})\end{array}$ \\
\hline 1 & $\begin{array}{l}\text { Chara fibrosa var. fibrosa f. fibrosa } \\
\text { (T. F. A. ex. Rob.) R. D. Wood, } \\
\text { em. }\end{array}$ & $6.6-12.1$ & 42,63 & $2.2-6.6$ \\
\hline 2 & $\begin{array}{l}\text { Chara fibrosa var. fibrosa f. } \\
\text { curtissi (T. F. A. ex. Rob.) } \\
\text { R. D. Wood, em. }\end{array}$ & $6.6-11.0$ & 14 & $2.2-6.6$ \\
\hline 3 & $\begin{array}{l}\text { Chara fibrosa var. hydropitys } \\
\text { f. hydropitys (Reich) R. D. } \\
\text { Wood, em. }\end{array}$ & $5.5-13.2$ & 14 & $4.4-8.8$ \\
\hline 4 & $\begin{array}{l}\text { Chara fibrosa var. hydropitys f. } \\
\text { schneckii (T. F. A. ex. Rob.) } \\
\text { R. D. Wood, em. }\end{array}$ & $6.6-13.2$ & 28 & $2.2-8.8$ \\
\hline
\end{tabular}

between 5.5-13.2 $\mu \mathrm{m}$ at overlapping range (Table 2). In Chara fibrosa var. fibrosa f. fibrosa, the nuclei carrying chromosome numbers 42 and 63 were not seen with recognisable differences in their diameter.

As indicated in the Table 2 a count of $n=14$ has been ascertained for two taxa (Figs. 1, 2) and $n=28$ (Fig. 3) for one. Chara fibrosa var. fibrosa f. fibrosa has been observed existing at two ploidy levels i.e. $n=42$ (Fig. 4) and $n=63$ (Fig. 5). It is worth mentioning here that the population carrying different chromosome numbers was growing side by side and no appreciable difference could be visualised with respect to their morphological details.

The length of the chromosome among the four taxa ranged between 2.2-8.8 $\mu \mathrm{m}$. It is interesting to note that the taxa having the highest chromosome number i.e. 42 and 63 and those having lowest chromosome number i.e. 14 were seen sharing a commonrange of chromosome length i.e. 2.2-6.6 $\mu \mathrm{m}$. The longest chromosome was seen in the taxon having the lowest chromosome number. 

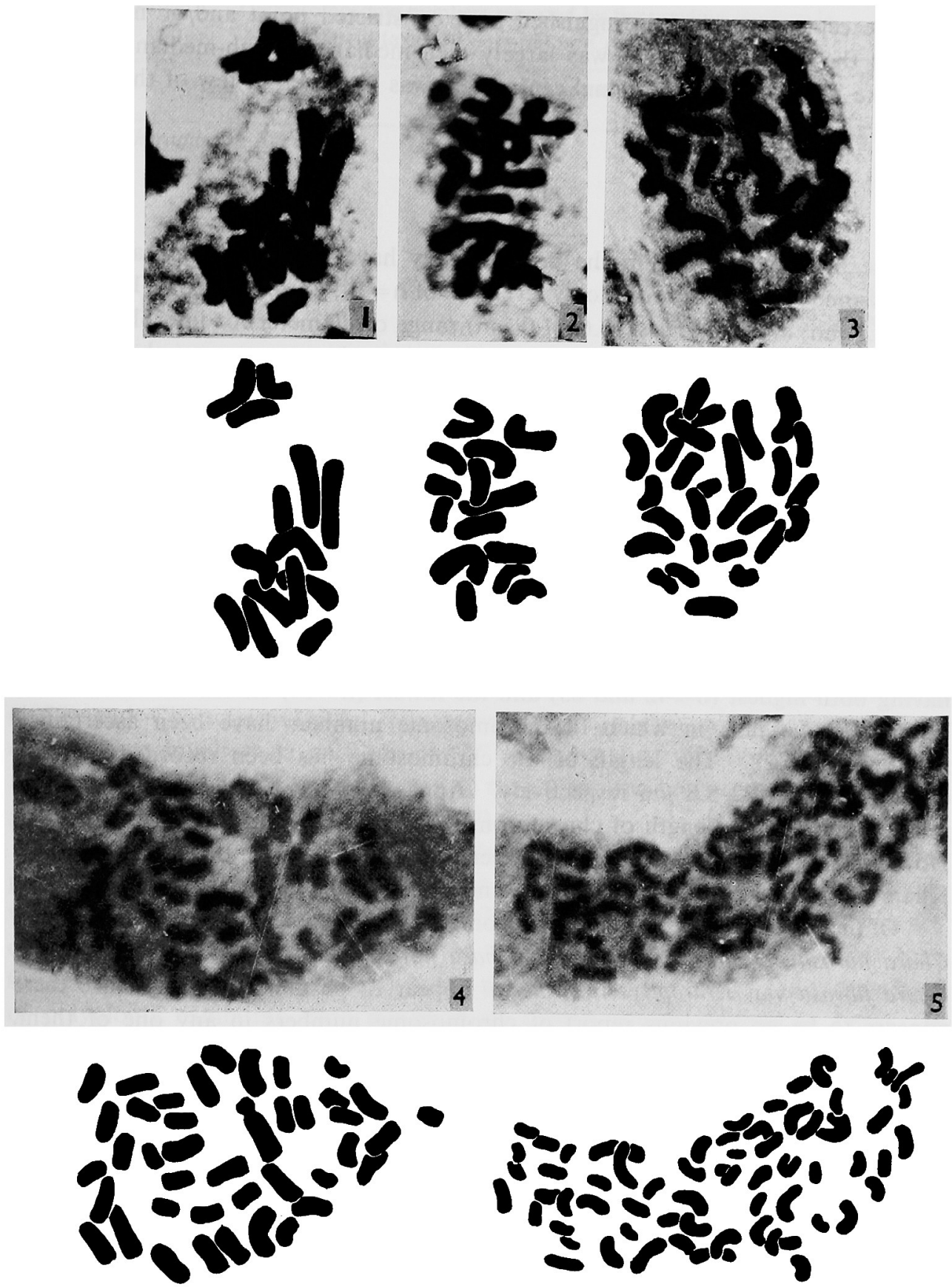

Figs. 1-5. Countable mitotic chromosomes at metaphase. 1, C. fibrosa var. fibrosa f. curtissii, $\mathrm{n}=14 . \times 3800.2, C$. fibrosa var. hydropitys f. hydropitys, $\mathrm{n}=14 . \times 3400.3$, C. fibrosa var. hydropitys $\mathrm{f}$. schneckii, $\mathrm{n}=28, \times 2300.4$ and 5, C. fibrosa var. fibrosa f. fibrosa. Fig. 4, $n=42 . \times 4300$. and Fig. $5, n=63 . \times 3600$. Below each microphotograph is its outline drawing. 
The centromere was distinguished as a constricted point and/or non-stained area on the chromosome. It was largely seen median and sub-median in all the four taxa but in first sub-terminal centromere was also seen in few of the chromosomes.

\section{Discussion}

The interphase nuclei in the present study have been observed carrying the chromosome numbers at four ploidy levels i.e. of $n=14,28,42$ and 63 . The highest (5.5-13.2 $\mu \mathrm{m})$ and the lowest $(6.6-11.0 \mu \mathrm{m})$ range of diameter for interphase nuclei have been recorded in the taxa carrying the lowest chromosome number $(n=14)$. Further the taxa with highest chromosome number $(\mathrm{n}=42$ and 63) bear comparatively smaller nuclei than those having comparatively lower chromosome number (Table 2). Therefore, no definite correlation appears to exist between the diameter of interphase nuclei and the chromosome number.

The length of the chromosomes among four taxa has been recorded between 2.2-8.8 $\mu \mathrm{m}$. Previous record of chromosome length in this genus is $0.3-5.9 \mu \mathrm{m}$ by Khan and Sarma 1967 and $0.8-7.2 \mu \mathrm{m}$ by Verma (1972). Therefore, the length of the chromosome in this genus may be considered from $0.3-8.8 \mu \mathrm{m}$. Further, the lowest chromosome length $(2.2-6.6 \mu \mathrm{m})$ has been found shared by the taxa having both highest $(n=42$ and 63) and the lowest $(n=14)$ chromosome numbers. The other two taxa in which the chromosome numbers have been ascertained $\mathrm{n}=14$ and $\mathrm{n}=28$. The length of the chromosome has been recorded between 4.4-8.8 $\mu \mathrm{m}$ and $2.2-8.8 \mu \mathrm{m}$ respectively. Apparently there appears to be no correlation between the length of chromosome and its number in the present context. However, an inverse relationship between the two has been reported earlier by Khan and Sarma (1967), Sarma and Ramjee (1971) and Sinha and Noor (1971).

Of the four investigated taxa, the chromosome numbers ascertained for three viz. Chara fibrosa var. fibrosa f. curtissii, Chara fibrosa var. hydropitys f. hydropitys, Chara fibrosa var. hydropitys $\mathrm{f}$. schneckii appear to be maiden report since there appears to be no previous report of chromosome numbers in any one of them. Chara fibrosa var. fibrosa f. fibrosa, in which the chromosome numbers have been ascertained as $n=42$ and 63 (Figs. 4,5 ) by the authors differs from the previous reports of Sarma and Khan (1965) and Ramjee and Bhatnagar (1978) who have recorded the chromosome number $n=14$ and $n=28$ respectively for the same taxon. Besides the four investigated taxa belonging to Chara fibrosa complex, six have been cytologically studied so far and the chromosome numbers in them have been reported $n=8,14,28$ and 42 (Table 3 ).

The chromosome numbers reported so far in different taxa belonging to the genus Chara are in multiple of "7" i.e. 7, 14, 28, 35, 42, 49, 56 and 70 (Hotchkiss 1963, Griffin and Proctor 1964, Tindal and Sawa 1964, Sarma and Khan 1966, 1967a, b, c, Sinha and Verma 1970, Sarma and Ramjee 1971, Noor and Mukherjee 1977 Ramjee and Bhatnagar 1978). Moutschen et al. (1956) suggested "7" as the basic chromosome number for the genus Chara and it has been further supported by Gillet (1959); Khan and Sarma (1967); Sinha and Noor (1967); Guerlesquin 
Table 3. The chromosome numbers reported by the previous workers in different taxa of Chara fibrosa Complex

\begin{tabular}{|c|c|c|c|}
\hline $\begin{array}{l}\text { Sl. } \\
\text { no. }\end{array}$ & Name of the taxa & $\begin{array}{l}\text { Chromosome } \\
\text { number }\end{array}$ & Authors and year \\
\hline \multirow[t]{2}{*}{1} & Chara fibrosa Ag. ex Bruz & $\mathrm{n}=14$ & $\begin{array}{l}\text { Sarma and Khan 1965a, b, c, } \\
1966,1967 a, b \text {, Sinha and } \\
\text { Noor } 1971\end{array}$ \\
\hline & & $\mathrm{n}=28$ & Hotchkiss 1963 \\
\hline 2 & C. fibrosa Ag. ex Bruz. & $\mathrm{n}=14$ & Khan and Sarma 1967 \\
\hline \multirow[t]{2}{*}{3} & $\begin{array}{l}\text { C. fibrosa var. hydropitys } \\
\text { Reich. R. D. Wood, em. }\end{array}$ & $\mathrm{n}=14$ & $\begin{array}{l}\text { Khan and Sarma 1967, Sinha } \\
\text { and Verma 1970, Noor } \\
\text { 1969, } 1970\end{array}$ \\
\hline & & $\mathrm{n}=8$ & Noor and Mukherjee 1975 \\
\hline 4 & C. fibrosa Ag. ex Bruz & $\begin{array}{l}\mathrm{n}=14 \\
\mathrm{n}=28 \\
\mathrm{n}=42\end{array}$ & $\begin{array}{l}\text { Sarma and Ramjee } 1971 \\
\text { Hotchkiss } 1963 \text {, Sarma and } \\
\text { Ramjee } 1971\end{array}$ \\
\hline 5 & $\begin{array}{l}\text { C. fibrosa f. erythrogyna (Griffith) } \\
\text { R. D. W. em. }\end{array}$ & $\begin{array}{l}\mathrm{n}=42 \\
\mathrm{n}=28 \\
\mathrm{n}=14\end{array}$ & $\begin{array}{l}\text { Sarma and Ramjee } 1971 \\
\text { Sinha and Noor } 1971 \\
\text { Ramjee and Bhatnagar } 1978\end{array}$ \\
\hline 6 & $\begin{array}{l}\text { C. fibrosa var. hydropitys (Reich) } \\
\text { R. D. W. em. }\end{array}$ & $\mathrm{n}=14$ & Ramjee and Bhatnagar 1978 \\
\hline
\end{tabular}

(1967); Sinha and Verma (1970); Sarma and Ramjee (1971); Noor and Mukherjee (1977) and Chatterjee (1979). The present findings also confirm the series of chromosome numbers in multiple of " 7 " in this genus. However, the count of $\mathrm{n}=63$ ascertained by the authors is new to the science and bridges the long prevailing gap of "7" in the series between 56 and 70 .

After reviewing the frequency and degree of polyploidy of the world charophytes, Guerlesquin (1967) suggested that the frequency of polyploidy is variable within each genus. Sarma and Ramjee (1971) have calculated the total frequency of polyploidy among different species of the genus Chara as $34.78 \%$. They have further asserted that among charophytes, C. zeylanica has reached the highest level of polyploidy exhibiting upto $n=70$ in its certain strains (Hotchkiss 1963). In the present investigation, count of $n=42$ and $n=63$ have been ascertained for C. fibrosa var. fibrosa f. fibrosa. Previous reports of chromosome number in this species were of $n=28$ and $n=42$ (Table 3 ). Therefore, it appears to be too early to deduce any polyploidy habit correlation because so far only a limited number of taxa belonging to this genus are cytologically worked out.

C. fibrosa var. fibrosa f. fibrosa has been observed existing at two ploidy levels in nature i.e. $n=42$ and 63 but without any morphological manifestation of the polyploidy. Such polyploids have also been reported in the higher plants to which Davis and Haywood (1963) called as "cryptic-polyploids".

\section{Summary and conclusions}

Four taxa belonging to the Chara fibrosa Complex (Wood and Imahori, 1965)viz. Ch. fibrosa var. fibrosa f. fibrosa, Ch. fibrosa var. fibrosa f. curtissii, Ch. fibrosa var. 
hydropitys f. hydropitys, Ch. fibrosa var. hydropitys f. schneckii were collected from three districts of North Bihar. Counts of $n=42$ and 63 have been ascertained for the first named taxon and $n=28$ for the last. In rest of the two taxa, the chromosome number has been recorded as $n=14$. Of the four, while the present counts in last three taxa are maiden report of the authors, it differs from the previous reports in the first. Present count $n=63$ has not so far been reported in the genus Chara and hence new to the science.

\section{Acknowledgment}

Authors are indebted to Dr. S.S. Prasad, Professor and Head of Botany, University of Bihar, Muzaffarpur for extending laboratory facilities and encouragements.

\section{References}

Chatterjee, P. 1979. Karyological investigation of Chara Wallichii A. Br. Cell and chromosome. Newsletter. 2(1): 21-23.

Davis, P. H. and Haywood, V. H. 1963. Principles of Angiosperm Taxonomy. Oliver and Boyd, Edinburgh and London.

Godward, M. B. E. 1948. The iron alum acetocarmine method for Algae. Nature $161: 203$.

Gillet, C. 1959 . Nombress chromosomique de plusieurs espèces de Charaphyceae (Généres Nitella et Chara). Rev. Cytol. Biol. Vég. 20: 229-234.

Griffin, W. and Proctor, V. W. 1964. A population study of Chara zeylanica in Texas, Okulahoma and New Mexico. Amer J. Bot. 51: 120-124.

Guerlesquin, M. 1967. Recherches caryotypiques et cytotaxonomiques cher les Charophyceae d'Europe Occidentale et d'Afrique du Nord. Ph. D. Thesis (France).

Hotchkiss, A. T. 1963. A first report of chromosome numbers in charophyte genus Lychnothamnus (Rupr.) Leonh. and comparison with the other charophyte genera. Proc. Linn. Soc. New South Wales 138: 368-372.

Khan, M. and Sarma, Y. S. R. K. 1967a. Studies on cytotaxonomy of Indian Charophyta I. Chara. Phykos 6(1 and 2): 36-47.

- and - 1967b. Studies on the cytotaxonomy of India Charophyte II. Nitella. Tbid. 6:48-61.

- and - 1967c. Some observations on the cytology of Indian Charophyta. Ibid. 6(1 and 2): $62-74$.

Moutschen, J. M., Dahmen, M. and Gillet, C. 1956. Sur les modifications induties par les hydreezide matique et isonicotinique dans les autheridies de Chara vulgaris L. La Cellude 58: 65.

Noor, M. N. 1965. Cytotaxonomic and cultural studies of some members of Chlorophyceae of Chhotanagpur. Ph. D. Thesis, Ranchi University, Ranchi (Bihar).

- 1969-1970. A preliminary report on chromosome numbers of some Indian Characeae. Jour. Ranchi Univ. 6 and $7: 232-239$.

- and Mukherjee, S. 1975. On the aneuploid chromosome number in Chara hydropitys Reich. from India. Cytologia 40: 803-807.

- and - 1977. Some new records of chromosome numbers in India Charophyta. Cytologia 42: 227-232.

Ramjee and Bhatnagar, S. K. 1978. Studies on charophytes from Rohilkhand Division I. Moradabad: Taxonomic enumeration and chromosome counts. Phykos $17(1,2)$ : 87-92.

Sarma, Y. S. R. K. and Khan, M. 1965a. Chromosome numbers in some Indian species of Chara. Phycologia 4(3): 173-176.

- and - 1965b. Some new observations on karyology of Chara zeylanica Klein ex. Willd. Curr. Sci. 34(9): 293-294.

- and - 1965c. A preliminary report on the survey of chromosome numbers of Indian Charo- 
phyta. The Nucleus 8: 33-38.

- and - 1966. A new form of Lychnothamnus barbatus Leonh. f. iyengarii f. nov. Phykos 5(1, 2): 195-197.

- and - 1967a. Some effects of X-ray on the chromosomes of Nitella flagelliformis Br. Nucleus 10: 90-93.

- and - 1967b. On two new charophytes from India. Hydrobiologia 30: 405-410.

- and - 1967c. Dioecism and monoecism as taxonomic criteria in charophyte. Curr. Sci. 36: 245-246.

- and Ramjee 1971a. Chromosome number in three taxa of Indian Charophyta. J. Cytol. Genet. 4: 32-36.

- and - 1971b. Significance of chromosome numbers in charophyta-A discussion. Caryologia 24: 391-401.

Sinha, J. P. and Noor, M. N. 1967. Chromosome numbers in some members of Chlorophyceae of Chhotanagpur (India). Phykos 4: 74-75.

- and - 1971. Studies on the karyology of some members of Charophyta of Bihar. Phykos 10: 112-117.

- and Verma, B. N. 1970. Cytological analysis of the charophytes of Bihar. Phykos 9(2): 92-99.

Tindal, D. R. and Sawa, T. 1964. Chromosomes of the Characeae of the Wood's Hole (Massachusetts) region. Amm. Jour. Bot. 51 : 943-949.

Wood, R. D. and Imahori, K. 1965. A Revision of the Characeae, Monography and Iconography, Verlag von. J. Cramer Publication. 